\title{
Effects of calcium salt supplementation on dairy cow performances in early lactation. Influence of the nature of concentrates
}

\author{
Y Elmeddah ${ }^{1 *}$, M Doreau $^{1 * \star}$, J Rouel $^{2}$, Y Chilliard ${ }^{1}$ \\ 1 INRA, Laboratoire Sous-Nutrition des Ruminants, Theix, 63122 Saint-Genès-Champanelle; \\ 2 INRA, Domaine d'Orcival, 63120 Rochefort-Montagne, France
}

(Received 2 November 1993; accepted 17 February 1994)

\begin{abstract}
Summary - Two feeding trials were carried out on dairy cows for the first 12 weeks of lactation. Diets were based on grass silage and ensiled beet pulps and distinguished by the nature of concentrates: rich in starch (S), starch + lipids (SL), and fibre + lipids (FL1) for trial 1; fibre (F) and fibre + lipids (FL2) in trial 2. The lipid supplement used was calcium salts of palm oil fatty acids. Lipid-supplemented diets contained $c a 6 \%$ fatty acids in dry matter. Results were analysed for the first 6 weeks of lactation (period 1) then for the following 6 weeks (period 2). Whatever the basal diet, calcium salt supply did not modify milk yield ( 30.7 and $29.6 \mathrm{~kg}$ on average for trials 1 and 2 , respectively). In trial 1 , lipid supply did not modify protein content during weeks $1-6$ but decreased it during weeks $7-12(31.5,32.1$ and 31.4 $\mathrm{g} / \mathrm{kg}$ during weeks $1-6,28.8,27.2$ and $26.4 \mathrm{~g} / \mathrm{kg}$ during weeks $7-12$ for diets $\mathrm{S}$, SL and FL 1, respectively). Although non-significant, the same trends were observed in trial 2 ( 31.4 and $30.7 \mathrm{~g} / \mathrm{kg}$ during weeks 1-6, 29.4 and $27.5 \mathrm{~g} / \mathrm{kg}$ during weeks 7-12 for diets $F$ and FL2, respectively). In trial 1, during weeks 7-12, lactose content was lower for diet FL1 than for diet SL ( $48.0 \mathrm{vs} 49.4 \mathrm{~g} / \mathrm{kg})$. For the 2 trials and the 2 periods, butterfat content did not vary $(45.2,47.4,45.2,44.6,47.0 \mathrm{~g} / \mathrm{kg}$ during weeks 1-6, $40.5,40.4,38.2,38.1,39.0 \mathrm{~g} / \mathrm{kg}$ during weeks $7-12$ for diets $\mathrm{S}, \mathrm{SL}, \mathrm{FL} 1, \mathrm{~F}$ and FL2, respectively). Lipid supply decreased the proportion of short- and medium-chain fatty acids (6-14 carbons) in both trials and both periods, increased C16:0 in both trials during weeks $1-6$ only, and did not modify $\mathrm{C} 18: 0$ and increased C18:1 during the 2 periods in trial 1 and during weeks 7-12 in trial 2 . No difference in proportion of these fatty acids was observed between diets SL and FL1.
\end{abstract}

cow / milk production / milk composition / calcium salt / carbohydrate

Résumé - Effet d'une supplémentation en lipides sur les performances des vaches laitières en début de lactation. Influence de la nature de l'aliment concentré. Deux expériences d'alimentation ont été menées sur vaches laitières pendant les 12 premières sem de lactation. Les rations étaient toutes à base d'ensilage d'herbe et de pulpes de betteraves ensilées, et se distinguaient par la nature de l'aliment concentré : riche en amidon (S), amidon + lipides (SL) et fibres + lipides (FL1) dans l'essai 1, fibres

\footnotetext{
* Present address: INES, Agronomie, Route de Hasnaoua, 15000 Tizi-Ouzou, Algeria.
}

** Correspondence and reprints. 
(F) et fibres + lipides (FL2) dans l'essai 2. Le supplément lipidique était constitué de savons de calcium d'acides gras d'huile de palme, et les rations enrichies en lipides contenaient environ $6 \%$ d'acides gras dans la matière sèche. Les performances des vaches ont été analysées sur les 6 premières sem de lactation (période 1), et sur les 6 suivantes (période 2). Quel que soit le régime, la supplémentation lipidique n'a pas modifié la production laitière $(30,7$ et $29,6 \mathrm{~kg}$ en moyenne pour les essais 1 et 2). Dans l'essai 1, elle n'a pas modifié le taux protéique en période 1 mais l'a diminué en période $2(31,5-32,1$ et $31,4 \mathrm{~g} / \mathrm{kg}$ en période $1 ; 28,8-27,2$ et $26,4 \mathrm{~g} / \mathrm{kg}$ en période 2 respectivement pour les régimes $S, S L$, et $P L 1$ ). Bien que non significatives, les mêmes tendances ont été observées dans l'essai $2(31,4$ et $30,7 \mathrm{~g} / \mathrm{kg}$ en période $1,29,4$ et $27,5 \mathrm{~g} / \mathrm{kg}$ en période 2 respectivement pour les régimes $P$ et $P L 2$. Dans l'essai 1, en période 2, la teneur en lactose a été plus faible $(P<0,05)$ pour le régime $P L 1$ que pour le régime $A L(48,0$ et $49,4 \mathrm{~g} / \mathrm{kg})$. Dans les 2 essais, le taux butyreux n'a pas varié $(45,2$ - 47,4-45,2-44,6 et 47,0 $\mathrm{g} / \mathrm{kg}$ en période $1 ; 40,5-40,4-38,2-38,1$ et $39,0 \mathrm{~g} / \mathrm{kg}$ en période 2 , respectivement pour les régimes $S, S L, P L 1, P$ et $P L 2)$. La supplémentation lipidique a réduit la proportion d'acides gras courts et moyens ( 6 à 14 carbones) pour les 2 essais et les 2 périodes, a accru le C16:O pour les 2 essais en période 1 seulement, n'a pas modifié le C18:0 et a accru le C18:1 pendant les 2 périodes dans l'essai 1, en période 2 dans l'essai 2. Aucune différence de proportion de ces acides gras n'a été observée entre les régimes $S L$ et $P L 1$.

vache / production laitière / composition du lait/savons de calcium / glucides

\section{INTRODUCTION}

Calcium salts are widely used as fat supplements for dairy rations. They help disturbances in ruminal digestion (Jenkins and Palmquist, 1984; Doreau et al, 1989) and are easy to incorporate into concentrates. Effects of calcium salts on milk production and composition have been recently reviewed (Chilliard et al, 1993). However, most of the numerous experiments carried out on the utilization of lipid supplements in dairy cows have been made after the peak of lactation, whereas lipid supplementation is often made in early lactation, due to the high energy value of lipids. The effects of calcium salts may be different in a period of lipid mobilization and low appetite as in the subsequent period of lactation. Moreover, the response of dairy cows to calcium salt supplementation could depend on the nature of the diet. Klusmeyer et al (1989a,b), using a small number of cows, did not show any interaction between calcium salts and protein supply or forage/concentrate ratio. In the same way, the percentage of concentrates did not interfere with calcium salt supplementation in a trial by Canale et al (1990a). However, other dietary factors such as the nature of concentrates have not been studied in interaction with lipid supplementation.

For these reasons, 2 experiments were carried out to analyze the response to calcium salt supplementation: 1) according to the stage of lactation; and 2) according to the nature of concentrates, either starchy or fibrous. For material reasons, these 2 interactions could not be studied simultaneously. Two experiments were therefore performed in 2 successive years.

\section{MATERIALS AND METHODS}

\section{Animals and diets}

\section{Trial 1}

Thirty multiparous Holstein cows were used between 2 weeks before calving and 12 weeks after calving. They were matched into 3 groups according to the nature of concentrate offered: starch (S), starch and lipids (SL), and fibre and lipids (FL). Groups were constituted according to liveweight, butterfat and protein content in the first 12 weeks of the previous lactation and 
expected milk yield at peak. The expected milk yield at peak was calculated from that of the previous lactation. During the course of the trial, one cow of group $S$ and 2 cows of group FL were removed due to strong mastitis.

The 3 diets were composed of the same basal diet, made of a mixture of natural grassland silage and beet pulp silage (3:1 on dry matter (DM) basis). This basal diet was complemented by one of the 3 experimental concentrates rich in starch, starch and lipids, or fibre and lipids. Lipids were calcium salts of palm oil fatty acids (Megalac, Volac Ltd, UK). The ingredient composition of concentrates is given in table I. Diets $S$ and SL differed mainly by the contents of starch and lipids, diets $S L$ and FL by the content of starch (table II). Moreover, cows received $200 \mathrm{~g}$ of mineral premix daily, containing $20 \% \mathrm{P}, 16 \%$ $\mathrm{Ca}, 3 \% \mathrm{Mg}, 3.9 \% \mathrm{Na}$, and vitamins $\mathrm{A}, \mathrm{D} 3$ and $\mathrm{E}$.

Cows were adapted to experimental diets for 2 weeks before calving. Silages were given ad libitum at $08.00 \mathrm{~h}$, concentrates were given at 08.00 and $16.00 \mathrm{~h}$. Energy supply from concentrates was determined from the expected milk yield and forage intake. The amount of concentrates offered was calculated according to the energy value of the 3 concentrates (table II) so that, for a same milk yield, the same percentage of energy originated from concentrates in the 3 groups. The energy value of feeds was determined from INRA (1989) and that of calcium salts was taken as $3.37 \mathrm{UFL} / \mathrm{kg}$ DM (Doreau et al, $1992 \mathrm{~b})$. The amount of forage offered was calculated from that of the previous day, with an expected proportion of refusals of about $10 \%$.

\section{Trial 2}

Twenty-two multiparous Holstein cows were used in this experiment. They were matched in 2 groups receiving either diet $F$ or diet $F L$. The constitution of groups, duration of the experiment and principles of feeding were the same as in trial 1. The forage was a cocksfoot silage. The composition of concentrate $\mathrm{F}$ is given in table I. The concentrates of diets F and FL differed by the incorporation of calcium salts in the latter. Concentrate FL was the same as in trial 1. Excessive silage refusals and diarrhea were registered at the beginning of the experiment, in late pregnancy. For this reason, $1.7 \mathrm{~kg} \mathrm{DM}$ of natural grassland hay were given to cows daily, and the problems stopped.

\section{Measurements and analyses}

The same measurements were made in both trials. The animals were weighed at calving then every 2 weeks. The amounts of feed delivered

Table I. Composition of concentrates of trials 1 and 2.

\begin{tabular}{|c|c|c|c|c|}
\hline Ingredient & $s$ & $F$ & $S L$ & $F L$ \\
\hline Barley & 53.0 & - & 35.0 & - \\
\hline Wheat & 15.5 & - & 11.0 & - \\
\hline Corn gluten feed & - & 43.0 & - & 29.0 \\
\hline Beet pulp & - & 29.5 & - & 20.0 \\
\hline Soybean meal & 23.0 & 19.0 & 15.0 & 15.0 \\
\hline Formaldehyde-treated soybean-rapeseed meal & - & - & 21.0 & 18.0 \\
\hline Ca salts a & - & - & 12.0 & 12.0 \\
\hline Beet molasses & 4.0 & 4.0 & 4.0 & 4.0 \\
\hline Limestone & 2.5 & 2.5 & - & - \\
\hline Dicalcium phosphate & 1.0 & 1.0 & 1.0 & 1.0 \\
\hline Magnesium oxide & 0.5 & 0.5 & 0.5 & 0.5 \\
\hline Sodium chloride & 0.5 & 0.5 & 0.5 & 0.5 \\
\hline
\end{tabular}

a Calcium salts of paim oil fatty acids (Megalac, Volac Ltd) contain $83.7 \%$ FA as $1.5 \% \mathrm{C} 14: 0,50.1 \% \mathrm{C} 16: 0,4.2 \%$ C18:0, $34.1 \%$ C18:1, $7.8 \%$ C18:2 and $3.0 \%$ C18:3. 
Table II. Chemical composition of ingested diets in trials 1 and 2.

ONa CPa NDFa ADFa Starchab Fattyacidsa Ca NEK(UFL/kgDM) PD/a,d

\begin{tabular}{crrrrrrrrr} 
Trial 1 & & & & & & & & & \\
S & 923 & 177 & 417 & 209 & 146 & 23 & 10.9 & 0.94 & 105 \\
SL & 920 & 172 & 434 & 225 & 96 & 57 & 11.8 & 1.02 & 106 \\
FL & 912 & 190 & 466 & 233 & 35 & 62 & 13.0 & 1.03 & 108 \\
Trial 2 & & & & & & & & & \\
F & 878 & 210 & 503 & 222 & - & 29 & 11.7 & 0.90 & 103 \\
FL & 881 & 230 & 478 & 219 & - & 61 & 11.7 & 0.98 & 112 \\
\hline
\end{tabular}

a In $\mathrm{g} / \mathrm{kg} \mathrm{DM}$; b calculated from tabulated values for diets of trial 1 (INRA, 1989); ${ }^{\circ}$ net energy for lactation (INRA, 1989); digestive protein in the intestines (INRA, 1989).

to cows were weighed every day and refusals 4 times per week. DM content of feeds was determined by drying for $48 \mathrm{~h}$ at $80^{\circ} \mathrm{C}$ once a week for concentrates and 4 times per week for forages and refusals. Milk yield was recorded every day. Analyses of its composition were made on samples taken twice a week, on morning and evening milkings. Contents in fat, protein and lactose were determined by infrared spectrophotometry (Milkoscan 605, Foss Electric, Hillerod, Denmark). Milk fatty acids were determined on samples of the 2 nd and the 8 th week of lactation by GLC on butyl esters, after extraction and transesterification of fatty acids (Chilliard et al, 1991).

In feeds, $\mathrm{N}$ was determined by Kjeldahl, ADF and NDF method according to Goering and Van Soest (1970); Ca was determined by atomic absorption spectrophotometry. Fatty acids were determined with the methanol/chloroform extraction of Folch et al (1957) followed by an extraction with ethanol/hexane/hydrochloric acid. After saponification and methylation, fatty acids were analysed by GLC according to Ferlay et al (1992).

Energy and nitrogen balances were calculated from feed values and cows' requirements (INRA, 1989). Liveweight variations were corrected to take account of variations in digestive contents, assuming that they increased by $4 \mathrm{~kg}$ when $\mathrm{DM}$ intake increased by $1 \mathrm{~kg}$ (Chilliard et al, 1987).

Blood samples were taken before the morning feed at the jugular vein, on the 2nd and 8th week of lactation. After centrifugation, the plasma was kept at $-20^{\circ} \mathrm{C}$ until analysis. All plasma metabolite concentrations were determined using an auto- analyser (Isamat, Isa-Biologie, Cachan, France) and commercial kits for glucose (Merckotest, Merck, Nogent-sur-Marne, France), non-esterified fatty acids (NEFA C test, Wako, Biolyon, Dardilly, France, as described by Chilliard et al, 1984), total and free cholesterol (Boehringer, Mannheim, Germany), and phospholipids (B test, Wako, Biolyon, Dardilly, France). 3-Hydroxybutyrate was determined automatically as described by Bamouin et $a$ l (1986) and urea with the urease method (Gutmann and Bergmeyer, 1974).

Results were analysed separately within each period: weeks 1-6 (period 1), and weeks 7-12 (period 2), by analysis of variance using the GLM procedure of SAS (1985). Expected milk yield, and fat-corrected milk (FCM), butterfat and protein content, were used as covariates for the corresponding parameters, their effect being significant. In trial 1, when the effect of treatment was significant, means were compared by least square means analysis.

\section{RESULTS}

\section{Trial 1}

\section{Effect of lipid supplementation}

During period 1, cows fed diet SL consumed daily $0.61 \mathrm{~kg}$ more FA (fatty acids) and 0.94 
$\mathrm{kg}$ less starch than cows fed diet $\mathrm{S}$. Ca salts $(0.7 \mathrm{~kg}$ daily) represented $59 \%$ of FA and $13 \%$ of the net energy consumed. The DM intake, milk production and nutritional balances did not vary significantly. However, milk fat was increased non-significantly by $2.2 \mathrm{~g} / \mathrm{kg}$ with diet SL compared with diet S (table III). Except for C4:0, proportions and secretions of short- and medium-chain fatty acids were significantly lower for diet SL than for diet S. Conversely, C16:0 and C18:1 were higher in milk of cows fed diet $S L$ than diet $S$ (table IV). Concentrations in free and esterified cholesterol and phospholipids tended to be higher with diet SL than with diet $\mathrm{S}$. Other plasma metabolites did not vary with diet (table V).

During period 2, the proportion of Ca salts in total FA and net energy supply was the same as in period 1. From one period to the other, milk yield increased by 0.8 and $1.3 \mathrm{~kg}$ for cows fed diets $S$ and SL, respectively.
At the same time, butterfat dropped by 4.7 and $7.0 \mathrm{~g} / \mathrm{kg}$ and protein content dropped by 2.7 and $4.9 \mathrm{~g} / \mathrm{kg}$ (table (II). Protein content was significantly lower by $1.6 \mathrm{~g} / \mathrm{kg}$ with diet SL compared with diet S. Milk fatty acid pattern was modified by lipid supplementation in the same way as in period 1, except that palmitic acid was not increased (table IV). Energy balance was significantly improved by lipid supplementation (table III). Among plasma metabolites, only free and esterified cholesterol and phospholipids were higher with diet SL than with diet $S$ (table V).

\section{Effect of nature of carbohydrates}

Mean contents in organic matter, PDI, UFL and FA were the same for diets SL and FL; NDF was slightly higher and starch 2.7 times lower for diet FL than for diet SL (table II). No significant difference was observed in food

Table III. Feed intake, milk production and composition in trial 1.

\begin{tabular}{|c|c|c|c|c|c|c|c|c|}
\hline \multirow[t]{3}{*}{ Item } & \multicolumn{8}{|c|}{ Dietary treatments } \\
\hline & \multicolumn{4}{|c|}{$1-6$ weeks postpartum } & \multicolumn{4}{|c|}{ 7-12 weeks postpartum } \\
\hline & $S$ & $S L$ & $F L$ & $R S D^{\dagger}$ & $S$ & $S L$ & $F L$ & RSDt \\
\hline Body weight $(\mathrm{kg})$ & 600 & 614 & 614 & 30 & 598 & 609 & 599 & 33 \\
\hline Forage intake $(\mathrm{kg} / \mathrm{d})$ & 11.7 & 12.3 & 11.3 & 1.3 & 12.9 & 13.6 & 12.3 & 1.3 \\
\hline DM intake $(\mathrm{kg} / \mathrm{d})$ & 18.8 & 18.4 & 17.7 & 1.6 & 20.9 & 20.1 & 19.3 & 1.7 \\
\hline Milk $(\mathrm{kg} / \mathrm{d})^{\mathrm{b}}$ & 30.5 & 30.5 & 29.9 & 3.1 & 31.3 & 31.8 & 30.4 & 3.3 \\
\hline $\mathrm{FCM}(\mathrm{kg} / \mathrm{d})^{\mathrm{b}, c}$ & 32.8 & 33.9 & 31.4 & 3.4 & 31.4 & 32.1 & 29.3 & 3.0 \\
\hline Milk fat $(\mathrm{g} / \mathrm{kg})^{\mathrm{b}}$ & 45.2 & 47.4 & 45.2 & 3.6 & 40.5 & 40.4 & 38.2 & 3.0 \\
\hline Milk protein $(\mathrm{g} / \mathrm{kg})^{\mathrm{b}}$ & 31.5 & 32.1 & 31.4 & 3.0 & $28.8^{A}$ & $27.2^{\mathrm{B}}$ & $26.4^{\mathrm{B}}$ & 1.6 \\
\hline Milk lactose $(\mathrm{g} / \mathrm{kg})$ & 48.9 & 48.7 & 48.2 & 1.0 & $49.4^{A}$ & $49.4^{A}$ & $48.0^{\mathrm{B}}$ & 1.4 \\
\hline Milk fat $(g / d)$ & 1381 & 1446 & 1287 & 180 & $1260^{A B}$ & $1296^{A}$ & $1134^{B}$ & 151 \\
\hline Milk protein $(g / d)$ & 941 & 944 & 898 & 121 & $909^{A}$ & $863^{A B}$ & $789^{B}$ & 101 \\
\hline Milk lactose $(\mathrm{g} / \mathrm{d})$ & 1507 & 1492 & 1433 & 180 & 1565 & 1570 & 1444 & 222 \\
\hline Change in body weight $(\mathrm{kg})$ & -43.5 & -40.7 & -33.5 & 33.0 & 4.0 & 2.6 & -5.9 & 25.1 \\
\hline Energy balance (UFL/d) & -2.73 & -1.88 & -1.35 & 1.41 & $-0.20^{A}$ & $0.64^{B}$ & $1.44^{\mathrm{B}}$ & 0.83 \\
\hline Protein balance $(\mathrm{g} / \mathrm{d})^{\mathrm{d}}$ & 95 & 70 & 117 & 134 & 363 & 376 & 467 & 111 \\
\hline
\end{tabular}

\footnotetext{
$\uparrow$ Residual standard deviation; ${ }^{b}$ adjusted means; ${ }^{c}$ FCM: $4 \%$ fat-corrected milk; d Expressed in protein digestible in the intestines (PDI). A,B,C Means on the same line for the same period with different superscripts are different $(P<0.05)$.
} 
Table IV. Mean fatty-acids composition of milk fat (in weight of fatty acids) in trial 1.

\begin{tabular}{|c|c|c|c|c|c|c|c|c|}
\hline & \multicolumn{8}{|c|}{ Dietary treatments } \\
\hline & \multicolumn{4}{|c|}{$1-6$ weeks postpartum } & \multicolumn{4}{|c|}{ 7-12 weeks postpartum } \\
\hline & $s$ & $S L$ & $F L$ & $R S D t$ & $S$ & $S L$ & $F L$ & $R S D^{t}$ \\
\hline \multicolumn{9}{|c|}{ Fatty acids $(\mathrm{g} / 100 \mathrm{~g})$} \\
\hline $\mathrm{C} 4: 0$ & 3.5 & 3.7 & 3.2 & 0.4 & 3.4 & 3.5 & 3.2 & 0.4 \\
\hline $\mathrm{C} 6: 0$ & $2.7^{a}$ & $2.2^{b}$ & $2.0^{\mathrm{b}}$ & 0.3 & $2.6^{a}$ & $2.2^{b}$ & $2.0^{\mathrm{b}}$ & 0.3 \\
\hline C8:0 & $1.8^{\mathrm{a}}$ & $1.3^{b}$ & $1.2^{b}$ & 0.2 & $1.7^{\mathrm{a}}$ & $1.3^{\mathrm{b}}$ & $1.2^{b}$ & 0.2 \\
\hline C10:0 & $3.8^{a}$ & $2.4^{b}$ & $2.5^{b}$ & 0.6 & $3.9^{a}$ & $2.7^{b}$ & 2.46 & 0.6 \\
\hline $\mathrm{C} 12: 0$ & $4.3^{\mathrm{a}}$ & $2.6^{b}$ & $3.0^{\mathrm{b}}$ & 0.7 & $4.5^{\mathrm{a}}$ & $2.8^{b}$ & $2.9^{b}$ & 0.6 \\
\hline C14:0 & $11.5^{a}$ & $8.6^{b}$ & $7.9^{b}$ & 1.2 & $12.7^{a}$ & $9.4^{b}$ & $9.2^{b}$ & 1.1 \\
\hline C16:0 & $29.9^{\mathrm{a}}$ & $33.2^{b}$ & $31.9^{a b}$ & 1.8 & 35.7 & 35.4 & 36.7 & 2.1 \\
\hline C16:1 & 1.7 & 2.0 & 1.9 & 0.4 & $1.5^{\mathrm{a}}$ & $1.8^{\mathrm{ab}}$ & $1.9 \mathrm{~b}$ & 0.3 \\
\hline C18:0 & 11.7 & 11.7 & 12.0 & 1.5 & 9.4 & 10.0 & 9.8 & 1.4 \\
\hline C18:1. & $21.5^{\mathrm{a}}$ & $26.2^{b}$ & $28.2^{\mathrm{b}}$ & 3.3 & $17.6^{a}$ & $24.8^{\mathrm{b}}$ & 25.16 & 3.1 \\
\hline $\mathrm{C} 18: 2$ & 2.0 & 2.3 & 2.3 & 0.5 & $1.8^{a b}$ & $2.1^{\mathrm{a}}$ & $1.6^{\mathrm{b}}$ & 0.4 \\
\hline C18:3 & $0.6^{\mathrm{a}}$ & $0.4^{b}$ & $0.4^{\mathrm{b}}$ & 0.2 & 0.6 & 0.4 & 0.4 & 0.2 \\
\hline \multicolumn{9}{|c|}{ Secretion of main fatty acids in milk $(g / d)$} \\
\hline $\mathrm{C} 6: 0-\mathrm{C} 8: 0$ & $62^{\mathrm{a}}$ & $50^{\mathrm{b}}$ & $39 \mathrm{c}$ & 7 & $54^{a}$ & $45^{b}$ & $36^{c}$ & 8 \\
\hline $\mathrm{C}_{10: 0}-\mathrm{C}_{14: 0}$ & $286^{a}$ & $207^{b}$ & $181^{b}$ & 34 & $284^{a}$ & $207^{b}$ & $180^{\circ}$ & 35 \\
\hline $\mathrm{C} 16: 0$ & $413^{a}$ & $479^{b}$ & $410^{a}$ & 61 & 450 & 460 & 416 & 67 \\
\hline C18:0 & 162 & 169 & 155 & 30 & 119 & 130 & 111 & 25 \\
\hline C18:1 & $298^{a}$ & $380^{\mathrm{b}}$ & $368^{b}$ & 79 & $221^{a}$ & $319^{\mathrm{b}}$ & $284^{b}$ & 46 \\
\hline C18:2 & 27 & 33 & 30 & 8 & $22^{a b}$ & $28^{a}$ & $18^{b}$ & 6 \\
\hline C18:3 & $9^{a}$ & $6^{b}$ & $5^{b}$ & 4 & 7 & 6 & 5 & 2 \\
\hline
\end{tabular}

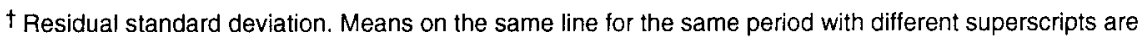
different $(P<0.05)$.

intake, milk production and composition, energy balance (table III) or fatty-acid composition (table IV) between the 2 diets. Nonsignificant trends in both butterfat content (47.4 and $45.2 \mathrm{~g} / \mathrm{kg}$ for diets SL and FL, respectively) and fatty acid composition resulted in significantly lower output of shortand medium-chain fatty acids and palmitic acid with diet FL than with diet SL (table IV). No significant effect of diet on plasma metabolites was observed.

During period 2, lactose content was significantly lower in milk of cows fed diet $F L$ than of cows fed diet SL. As in period 1, dif- ferences in fatty-acid composition were not significant, except for C18:2, which was higher for diet SL than for diet FL. Output of short- and medium-chain fatty acids, of C18:1 and C18:2, were higher for diet SL than for diet FL (table IV). No difference between diets occurred for plasma metabolites (table V).

\section{Trial 2}

During period 1, FA amounted to 2.9 and $6.1 \%$ of total DM intake, on average, for diets $F$ and FL respectively. Although no significant 
Table V. Metabolite concentrations in plasma in trial 1.

Item

\begin{tabular}{|c|c|c|c|c|c|c|c|}
\hline & & & Die & ment & & & \\
\hline & 6 wee & postp & $\mathrm{um}$ & & 2 we & postp & rtum \\
\hline$S$ & . $S L$ & $F L$ & $R S D^{\dagger}$ & $S$ & $S L$ & $F L$ & $R S D t$ \\
\hline 63.0 & 59.7 & 56.6 & 4.5 & 69.0 & 66.6 & 64.2 & 4.6 \\
\hline 0.84 & 0.88 & 1.04 & 0.39 & 0.26 & 0.28 & 0.32 & 0.19 \\
\hline 0.69 & 0.76 & 0.90 & 0.31 & 0.51 & 0.60 & 0.62 & 0.20 \\
\hline 30.3 & 30.5 & 34.9 & 5.7 & 30.9 & 34.9 & 30.9 & 6.7 \\
\hline $28^{a}$ & $36^{b}$ & $39^{b}$ & 7 & $42^{a}$ & $57^{b}$ & $52^{b}$ & 9 \\
\hline $107^{a}$ & $133^{a b}$ & $139^{b}$ & 25 & $136^{a}$ & $206^{b}$ & $184^{b}$ & 33 \\
\hline $152^{a}$ & $198^{a b}$ & $211^{b}$ & 37 & $215^{a}$ & $322^{b}$ & $310^{b}$ & 59 \\
\hline
\end{tabular}

t Residual standard deviation. a,b.c Means on the same line for the same period with different superscripts are different $(P<0.05)$.

differences have been shown on milk production, cows fed diet $F$ produced on average $2 \mathrm{~kg}$ more fat-corrected milk daily and this milk was slightly richer in fat (table VI).
The fatty-acid pattern showed the same trends as in trial 1; ie a decrease in mediumchain fatty acids and an increase in palmitic acid (table VII). However, the increase in FA

Table VI. Feed intake, milk production and composition in trial 2.

Item

Dietary treatments

\begin{tabular}{|c|c|c|c|c|c|c|}
\hline & \multicolumn{3}{|c|}{$1-6$ weeks postpartum } & \multicolumn{3}{|c|}{$7-12$ weeks postpartum } \\
\hline & $F$ & $F L$ & $R S D+$ & $F$ & $F L$ & RSDt \\
\hline Body weight (kg) & 652 & 647 & 21 & 645 & 644 & 24 \\
\hline Forage intake $(\mathrm{kg} / \mathrm{d})$ & 10.3 & 10.8 & 1.2 & 10.4 & 11.5 & 1.2 \\
\hline DM intake (kg/d) & 18.4 & 17.5 & 1.4 & 20.0 & 19.2 & 2.0 \\
\hline Milk $(\mathrm{kg} / \mathrm{d})^{\mathrm{b}}$ & 28.8 & 29.8 & 3.9 & 29.5 & 31.1 & 4.9 \\
\hline FCM $(\mathrm{kg} / \mathrm{d})^{\mathrm{b}, \mathrm{c}}$ & 30.7 & 32.7 & 4.9 & 28.8 & 30.7 & 5.1 \\
\hline Milk fat $(\mathrm{g} / \mathrm{kg})^{\mathrm{b}}$ & 44.6 & 47.0 & 4.5 & 38.1 & 39.0 & 2.8 \\
\hline Milk protein $(\mathrm{g} / \mathrm{kg})^{\mathrm{b}}$ & 31.4 & 30.7 & 1.9 & 29.4 & 27.5 & 3.2 \\
\hline Milk lactose $(\mathrm{g} / \mathrm{kg})$ & 47.4 & 48.0 & 1.4 & 46.9 & 48.3 & 2.0 \\
\hline Milk fat $(\mathrm{g} / \mathrm{d})$ & 1294 & 1399 & 262 & 1131 & 1214 & 246 \\
\hline Milk protein $(\mathrm{g} / \mathrm{d})$ & 903 & 908 & 127 & 871 & 848 & 177 \\
\hline Milk lactose $(\mathrm{g} / \mathrm{d})$ & 1372 & 1425 & 214 & 1400 & 1497 & 271 \\
\hline Change in body weight $(\mathrm{kg})$ & -34.0 & -29.0 & 13.6 & -48.0 & -39.0 & 26.5 \\
\hline Energy balance (UFL/d) & -3.62 & -3.30 & 1.78 & -1.42 & -0.66 & 2.23 \\
\hline Protein balance $(\mathrm{g} / \mathrm{d})^{\mathrm{d}}$ & 47 & 103 & 184 & 308 & 465 & 327 \\
\hline
\end{tabular}

t Residual standard deviation; b adjusted means; c FCM: $4 \%$ fat-corrected milk; d expressed in protein digestible in the intestines (PDI). 
Table VII. Mean fatty-acid composition of milk fat (in weight of fatty acids) in trial 2.

\begin{tabular}{|c|c|c|c|c|c|c|}
\hline & \multicolumn{6}{|c|}{ Dietary treatments } \\
\hline & \multicolumn{3}{|c|}{ 1-6 weeks postpartum } & \multicolumn{3}{|c|}{ 7-12 weeks postpartum } \\
\hline & $F$ & $F L$ & $R S D^{t}$ & $F$ & $F L$ & $R S D^{t}$ \\
\hline \multicolumn{7}{|c|}{ Fatty acids $(g / 100 \mathrm{~g})$} \\
\hline $\mathrm{C} 4: 0$ & 2.6 & 2.8 & 0.6 & 2.2 & 2.6 & 0.6 \\
\hline C6:0 & 2.1 & 1.9 & 0.3 & 2.2 & 2.0 & 0.5 \\
\hline C8:0 & 1.2 & $1.0^{*}$ & 0.2 & 1.5 & $1.1^{\star \star}$ & 0.2 \\
\hline C10:0 & 2.9 & $1.8^{* *}$ & 0.5 & 3.8 & $2.4^{\star \star}$ & 0.5 \\
\hline C12:0 & 3.3 & $2.9^{* *}$ & 0.8 & 5.1 & $2.9^{\star \star}$ & 0.7 \\
\hline C14:0 & 9.3 & $6.9^{\star}$ & 1.5 & 13.5 & $8.6^{\star \star}$ & 1.1 \\
\hline C16:0 & 28.1 & $32.7^{\star}$ & 3.1 & 34.5 & 34.8 & 2.9 \\
\hline C16:1 & 1.9 & 2.0 & 0.6 & 1.3 & $1.7^{\star \star}$ & 0.3 \\
\hline C18:0 & 14.3 & 13.8 & 2.1 & 10.5 & 11.7 & 1.4 \\
\hline C18:1 & 28.4 & 29.0 & 4.1 & 18.8 & $26.9^{\star \star}$ & 2.8 \\
\hline C18:2 & 1.5 & 1.7 & 0.3 & 1.4 & 1.8 & 0.6 \\
\hline C18:3 & 0.4 & 0.4 & 0.2 & 0.3 & 0.3 & 0.1 \\
\hline \multicolumn{7}{|c|}{ Secretion of fatty acids in milk ( $g / d)$} \\
\hline $\mathrm{C} 6: 0-\mathrm{C} 8: 0$ & 42 & 40 & 9 & 41 & 38 & 11 \\
\hline C10:0-C14:0 & 207 & $163^{*}$ & 43 & 267 & $179^{* *}$ & 60 \\
\hline C16:0 & 361 & $455^{\star *}$ & 71 & 389 & 422 & 89 \\
\hline C18:0 & 188 & 193 & 53 & 119 & 142 & 33 \\
\hline C18:1 & 372 & 408 & 109 & 214 & $326^{* *}$ & 63 \\
\hline C18:2 & 20 & 23 & 7 & 16 & 22 & 9 \\
\hline C18:3 & 5 & 5 & 3 & 4 & 3 & 1 \\
\hline
\end{tabular}

$\dagger$ Residual standard deviation; * significant difference between diets for a same period $(P<0.05)$; * significant difference between diets for a same period $(P<0.01)$.

with 18 carbon atoms due to lipid supplementation was not significant. Phospholipid and free and esterified cholesterol were significantly increased by lipid supplementation (table VIII).

Between periods 1 and 2, milk yield increased by 0.7 and $1.3 \mathrm{~kg}$ for diets $F$ and $F L$, respectively, while butterfat decreased by 6.5 and $8.0 \mathrm{~g} / \mathrm{kg}$ and protein content by 2.0 and $3.2 \mathrm{~g} / \mathrm{kg}$ for these 2 diets. Betweendiet differences in milk yield were of the same extent as in period 1 and not signifi- cant, but the differences in fat content were lower. Milk protein content was increased by $1.9 \mathrm{~g} / \mathrm{kg}$ for diet $\mathrm{F}$ compared with diet $\mathrm{FL}$, but this difference was not significant (table VI). Milk FA composition and secretion showed a decrease in medium-chain fatty acids and an increase in C18:1 due to lipid supplementation (table VII). Plasma metabolites varied with diet in the same way as in period 1 except that non-esterified fatty acid concentration was higher for diet $F L$ than for diet F (table VIII). 
Table VIII. Metabolite concentrations in plasma in trial 2.

\begin{tabular}{|c|c|c|c|c|c|c|}
\hline \multirow[t]{3}{*}{ Item } & \multicolumn{6}{|c|}{ Dietary treatments } \\
\hline & \multicolumn{3}{|c|}{$1-6$ weeks postpartum } & \multicolumn{3}{|c|}{ 7-12 weeks postpartum } \\
\hline & $F$ & $F L$ & $R S D+$ & $F$ & $F L$ & $R S D t$ \\
\hline Glucose (mg/dl) & 54.4 & 51.1 & 5.9 & 59.2 & 58.5 & 6.8 \\
\hline NEFA $(\mathrm{mmol} / \mathrm{l})$ & 1.54 & 1.39 & 0.52 & 0.34 & $0.58^{\star}$ & 0.23 \\
\hline 3-Hydroxybutyrate $(\mathrm{mmol} / \mathrm{l})$ & 0.78 & 0.97 & 0.25 & 0.44 & 0.71 & 0.31 \\
\hline Urea $(\mathrm{mg} / \mathrm{dl})$ & 33.2 & 35.7 & 5.7 & 36.1 & 38.6 & 5.9 \\
\hline Free cholesterol (mg/dl) & 26 & $32^{*}$ & 4 & 37 & $63^{*}$ & 11 \\
\hline Esterified cholesterol (mg/dl) & 110 & $140^{*}$ & 20 & 175 & $253^{*}$ & 29 \\
\hline Phospholipids (mg/dl) & 204 & $261^{*}$ & 45 & 290 & $396^{\star}$ & 63 \\
\hline
\end{tabular}

† Residual standard deviation; * significant difference between diets for a same period $(P<0.05)$.

\section{DISCUSSION}

\section{Effects of lipid supplementation}

Replacement in concentrates of carbohydrates by lipids on an energy basis did not modify voluntary intake of forage, so total energy intake did not vary. This result is mostly found when lipids are given instead of starchy products on the basis of their energy value (Chilliard, 1993), and especially with calcium salts when less than $700 \mathrm{~g}$ is fed daily (Chilliard et al, 1993). This absence of effect can be due to 1) the absence of ruminal disturbances (and thus of rumen fill) with calcium salts (Elmeddah et al, 1991); and 2) a lower lipid intake than necessary to obtain a metabolic limitation of intake. This is assessed by the lack of difference in plasma non-esterified fattyacid concentration when lipids are added (except for the second period of trial 2).

The absence of effects of calcium salt incorporation in the diet on milk yield has often been obtained in previous experiments: a positive effect is shown in about one third of the literature data (review of
Chilliard et al, 1993), without interaction with the level of production or the lipid intake. In this experiment, calcium salts were substituted with carbohydrates and energy supply was not different between diets. It can be thought that in trials in which calcium salts increased milk yield by about $3 \mathrm{~kg} / \mathrm{d}$ (Robb and Chalupa, 1987; Ferguson et al, 1988), the supplementation with calcium salts improved the energy supply.

The trend to a higher milk yield after lactation peak but not before is in contradiction with the model of Ostergaard et al (1981), who suggested a higher positive effect of lipids in early lactation. More recent data has indicated either the absence of effects of lactation stage (Hermansen, 1989) or even a positive effect only after peak of lactation (review of Doreau and Chilliard, 1992). In this experiment, the absence of effect of lipids can be related to the absence of variation in energy balance and in liveweight variations, which is observed more often than not (Chilliard, 1993). In contrast, some results obtained with calcium salts have shown a greater body weight loss with lipid-supplemented diets rich in concentrates, which could be related to the higher milk yield (Sklan et al, 1989). 
The extent of the decrease in milk protein content in this experiment was comparable with that observed in most experiments carried out with this kind of fat supplement (Chilliard et al, 1993). This decrease is generally attributed either to metabolic processes or to a limitation of microbial protein synthesis. Consequences of lipid incorporation on microbial protein synthesis are not clearly established, but in this experiment, protein supply was high and with calcium salts of palm oil no modification of ruminal digestion occurs (Elmeddah et al, 1991). As generally observed, this drop in protein content is mainly due to a dilution effect since total protein output is not modified. This experiment has shown that the effect of lipids on milk protein content is significant in full lactation, but not in early lactation. This trend has not been mentioned frequently, due to the low number of experiments carried out in early lactation. This has been found in trials of Bines et al (1978), Casper et al (1990) and Hoffman et al (1991). According to Doreau and Chilliard (1992) who have summarized several published and unpublished results, this result could be a consequence of dilution of proteins in milk, as milk yield increases with lipid supplementation more after peak of lactation than before.

No significant difference has been obtained with calcium salt incorporation on butterfat content. This trend is general with this kind of supplement (Chilliard et al, 1993). Only some experiments, such as those of Klusmeyer et al (1989a and 1989b), have shown an increase in fat content. Short- and medium-chain fatty acids are decreased when C16:0 and/or C18:1 are increased. Palmitic acid seems to increase more in early than in mid-lactation. This trend is in contrast to the data of Atwal et al (1990), who observed a higher variation of milk fatty-acid composition after peak of lactation, and of Schneider et al (1988), who did not show variations in fatty-acid com- position of milk samples in the second month of lactation. Our results could be due to the high percentage of palmitic acid in control diets in period 2; a high incorporation of palmitic acid in triglycerides could increase their melting point and thus could depress their secretion. Moreover, de novo synthesis of palmitic acid could be reduced when direct incorporation is increased. These hypotheses need to be verified. The absence of variation in $\mathrm{C} 18: 2$ could reflect the extent of hydrogenation of linoleic acid included in calcium salts, as shown by Ferlay et al (1992); the low level and the absence of variation in C18:0 could be a consequence of the activity of either the intestinal epithelium or mammary desaturase (Grummer, 1991).

The increase in plasma cholesterol and phospholipids with calcium salt supplementation, especially in mid-lactation, is consistent with the general effect of lipids (for example, Sharma et al, 1978; Smith et al, 1978; Gagliostro et al, 1991). Very little data has been obtained with calcium salts. Schneider et al (1988) did not observe variations in plasma cholesterol, whereas Crovetto et al (1989) found an increase. The cause of this inconsistency between trials remains unknown. The variability of response of non-esterified fatty-acid concentration (decrease for Schneider et al, 1988; an increase for Canale et al, 1990b, and Erickson et al, 1992; and the absence of variation in our trials except in period 2 of trial 2) is perhaps related to the variable effect of calcium salts on lipid mobilization (Chilliard, 1993) or to the nature of basal diet (type and level of carbohydrates).

\section{Effect of nature of concentrate}

The absence of a significant effect of nature of carbohydrates on milk production with diets rich in fat is attributed to 2 factors. Firstly, the comparison between diets rich in 
starch or fibre (independently of fat supply) does not exhibit differences in milk yield when the percentage of concentrates is lower than $50 \%$ of the diet (review of Coulon et al, 1989). Digestive processes, especially rate of digestion, are not very different between starchy and fibrous concentrates (Michalet-Doreau and Sauvant, 1989), and milk synthesis does not depend to a large extent on the equilibrium between the endproducts of digestion (Sutton, 1989). Secondly, although digestive interactions exist between unprotected lipids and the nature of carbohydrates (Ben Salem et al, 1993), calcium salts of palm oil fatty acids do not disturb ruminal digestion whatever the diet, especially the nature of concentrates (Elmeddah et al, 1991). Moreover, no interaction has been shown between the nature of carbohydrates and fat supplementation on milk yield with extruded soybeans (Casper et al, 1990) or calcium salts (Klusmeyer et al, 1989b).

Milk fat secretion is lower after the peak of lactation with diet FL than with diet SL. This is a consequence of a lower secretion of short- and medium-chain fatty acids, which arise from de novo synthesis from the end-products of carbohydrate digestion and metabolism, acetate and 3-Hydroxybutyrate. This is surprising because these precursors are generally the highest with a fibrous diet. The lack of difference between diets could be explained by too low a proportion of concentrate in the diet, as suggested by results of Sutton et al (1987), or by too small a difference in NDF content between diets SL and FL. However, the trend towards a lower butterfat content with diet FL than with diet SL cannot be explained.

The combination of lipids with fibre gave a lower lactose content than the combination of lipids with starch. This is certainly a consequence of the lack of glucose precursors with diet FL. Dietary effects on lactose content are not frequent, as lactose is the major component involved in milk osmotic pressure and regulates water secretion in the acini. To our knowledge, the decrease in lactose content with starchdeprived diets has only been observed in dogs (Romsos et al, 1981) and mares (Doreau et al, 1992a). However, a negative effect of lipid supplementation on milk lactose has already been shown in cows (Pan et al, 1972; MacLeod et al, 1977; Chilliard and Doreau, unpublished data), but the cause remains unknown. In our experiment, the conjunction of a low starch content (3.5\% of the diet) and of lipid addition in the diet could explain the effect on milk lactose. This can be related to the trend to a low glycemia with diet FL.

\section{CONCLUSION}

These experiments have shown that, for a same energy supply in the concentrates, substitution of carbohydrates by lipids did not significantly modify milk yield, whatever the diet. In particular, the effect of lipids was independent of the concentration in starch in the diet. This can be partly explained by the absence of effect of calcium salts on digestive processes in the rumen.

In these trials, it appeared that the negative effect of lipids on protein content did not occur in early lactation. This result needs further research since the lower protein content limits the practical use of lipids in dairy cow feeding.

\section{ACKNOWLEDGMENTS}

Calcium salts have been offered by Volac France, 2, rue Louis-Armand, 92600 Asnières, France. Thanks are due to the staff of Domaine Expérimental d'Orcival for care to animals and feeding, and to $\mathrm{J}$ Chabrot, J Fléchet and $\mathrm{R}$ Lefaivre for chemical analyses. 


\section{REFERENCES}

Atwal AS, Hidiroglou M, Kramer JKG, Binns MR (1990) Effects of feeding $\alpha$-tocopherol and calcium salts of fatty acids on vitamin $E$ and fatty-acid composition of cows' milk. J Dairy Sci 73, 2832-2841

Bamouin J, El Idibi N, Chilliard Y, Chacornac JP, Lefaivre R (1986) Microdosage automatisé sans déprotéinisation du 3-hydroxybutyrate plasmatique chez les bovins. Ann Rech Vét 17, 129-139

Ben Salem H, Krzeminski R, Ferlay A, Doreau M (1993) Effect of lipid supply on in vivo digestion in cows: comparison of hay and com sitage diets. Can J Anim Sci 73, 547-557

Bines JA, Brumby PE, Storry JE, Fulford RJ, Braithwailte GD (1978) The effect of protected lipids on nutrient intakes, blood and rumen metabolites and milk secretion in dairy cows during early lactation. J Agric Sci (Camb) 91, 135-150

Canale CJ, Burgess PL, Muller LD, Varga GA (1990a) Calcium salts of fatty acids in diets that differ in neutral detergent fiber: effect on lactation performance and nutrient digestibility. J Dairy Sci 73, 1031-1038

Canale CJ, Muller LD, McCahon HA, Whitsel TJ, Varga GA, Lormore MJ (1990b) Dietary fat and ruminally protected amino acids for high-producing dairy cows. $J$ Dairy Sci 73, 135-141

Casper DP, Schingoethe DJ, Eisembeisz WA (1990) Response of early lactation cows to diets that vary in ruminal degradability of carbohydrates and amount of fat. $J$ Dairy Sci $73,425-444$

Chilliard $Y$ (1993) Dietary fat and adipose tissue metabolism in ruminants, pigs and rodents: a review. J Dairy Sci 76, 3897-3931

Chilliard Y, Bauchart D, Barnouin J (1984) Determination of plasma non-esterified fatty acids in herbivores and man: a comparison of values obtained by manual or automatic chromatographic, titrimetric, colorimetric and enzymatic methods. Reprod Nutr Dev 24, 469-482

Chilliard Y, Rémond B, Agabriel J, Robelin J, Vérité R (1987) Variations du contenu digestif et des résenes corporelles au cours du cycle gestation-lactation. Bull Tech CRZV Theix, INRA 70, 117-131

Chilliard Y, Gagliostro G, Fléchet J, Lefaivre J, Sebastian I (1991) Duodenal rapeseed oil infusion in early and mid-lactation cows. 5. Milk fatty acids and adipose tissue lipogenic activities. J Dairy Sci 74, 1844-1854

Chilliard Y, Doreau M, Gagliostro G, Elmeddah Y (1993) Addition de lipides protégés (encapsulés ou savons de calcium) à la ration de vaches laitières. Effets sur les performances et la composition du lait. INRA Prod Anim 6, 139-150

Coulon JB, Faverdin P, Laurent F, Cotto G (1989) Influence de la nature de l'aliment concentré sur les performances des vaches laitières. INRA Prod Anim 2, 47-53
Crovetto GM, Sandrucci A, Steffanini L, Modenesi R, Corti $M$ (1989) Influence of protected fat (Ca-soaps) on milk production in dairy cows. Proc 40th Ann Meet Eur Assoc Anim Prod, Dublin, Ireland, 371-372

Doreau M, Chilliard Y (1992) Influence d'une supplémentation de la ration en lipides sur la qualité du lait chez la vache. INRA Prod Anim 5, 103-111

Doreau M, Ferlay A, Elmeddah Y, Bauchart D (1989) La "protection" des matières grasses utilisées dans l'alimentation des ruminants: conséquences sur la digestion. Rev Fr Corps Gras 36, 271-278

Doreau M, Boulot S, Bauchart D, Barlet JP, Martin-Rosset $W$ (1992a) Voluntary intake, milk production and plasma metabolites in nursing mares fed two different diets. J Nutr 122, 992-999

Doreau M, Ferlay A, Chilliard Y (1992b) Estimation de la valeur énergétique des savons de calcium. Proc Colloque "Les lipides dans l'alimentation des ruminats", GTV Pays de Loire Nantes, France, $2 \mathrm{p}$

Elmeddah Y, Doreau M, Michalet-Doreau B (1991) Interaction of lipid supply and carbohydrates in the diet of sheep with digestibility and ruminal digestion. J Agric Sci (Camb) 116, 437-445

Erickson PS, Murphy MR, Clark JH (1992) Supplementation of dairy cow diets with calcium salts of longchain fatty acids and nicotinic acid in early lactation. J Dairy Sci 75, 1078-1089

Ferguson JD, Torralba J, Schneider PL et al (1988) Response of lactating cows in commercial dairies to calcium salts of long-chain fatty acids. J Dairy Sci 71 (Suppl 1), 254

Ferlay A, Chilliard Y, Doreau M (1992) Effects of calcium salts differing in fatty acid composition on duodenal and milk fatty-acid profiles in dairy cows. $J \mathrm{Sci}$ Food Agric 60, 31-37

Folch J, Lees M, Sloane Stanley GH (1957) A simple method for the isolation and purification of total lipids from animal tissues. J Biol Chem 226, 497-509

Gagliostro G, Chilliard Y, Davicco MJ (1991) Duodenal rapeseed oil infusion in early and mid-lactation cows. 3. Plasma hormones and mammary apparent uptake of metabolites. J Dairy Sci 74, 1893-1903

Goering JK, Van Soest PJ (1970) Forage fiber analysis (apparatus, reagents, procedures and some applications). Handbook 379, ARS USDA, pp 20

Grummer RR (1991) Effect of feed on the composition of milk fat. J Dairy Sci 74, 3244-3257

Gutmann I, Bergmeyer HU (1974) Urea. In: Methods of Enzymatic Analysis (HU Bergmeyer) 2nd ed, Verlag Chemie Weinheim, Academic Press, 1791-1798

Hermansen JE (1989) Effect of dietary fat in relation to milk yield and stage of lactation in dairy cows. Acta Agric Scand 39, 389-396

Hoffman PC, Grummer RR, Shaver RD, Broderick GA, Drendel TR (1991) Feeding supplemental fat and undegraded intake protein to early lactation dairy cows. J Dairy Sci 74, 3468-3474 
INRA (1989) Ruminant Nutrition. Recommended Allowances and Feed Tables (R Jarrige, ed), John Libbey Eurotext, London, Paris, $389 \mathrm{pp}$

Jenkins TC, Palmquist DL (1984) Effect of fatty acids or calcium soaps on rumen and total nutrient digestibility of dairy rations. J Dairy Sci67, 978-986

Klusmeyer TH, Lynch GL, Clark JH, Nelson DR (1989a) Effects of source of protein and calcium salts of long-chain fatty acids (Ca-LCFA) on ruminal fermentation and flow of nutrients to the small intestine of lactating dairy cows. J Dairy Sci 72 (Suppl1), 482

Klusmeyer TH, Lynch GL, Clark JH, Nelson DR (1989b) Effect of amount of forage and calcium salts of longchain fatty acids (Ca-LCFA) on ruminal fermentation and flow of nutrients to the small intestine of lactating dairy cows. J Dairy Sci 72 (Suppl 1), 482

MacLeod GK, Yu Y, Schaeffer LR (1977) Feeding value of protected animal tallow for high yielding dairy cows. J Dairy Sci 60, 726-738

Michalet-Doreau B, Sauvant D (1989) Influence de la nature du concentré, céréales ou pulpe de betterave, sur la digestion chez les ruminants. INRA Prod Anim 2, 235-244

Ostergaard V, Danfaer A, Daugaard J, Hindhede J, Thysen I (1981) The effect of dietary lipids on milk production in dairy cows. Report 508, Natl Inst Anim Sci, Copenhagen, Denmark $140 \mathrm{p}$

Pan SP, Cook LJ, Scott TW (1972) Formaldehydetreated casein-safflower oil supplement for dairy cows. I. Effect on milk composition. J Dairy Res 39 , 203-207

Robb EJ, Chalupa W (1987) Lactational responses in early lactation to calcium salts of long-chain fatty acids. J Dairy Sci 70 (Suppl 1), 220

Romsos DR, Palmer HJ, Muiruri KL, Bennink MR (1981) Influence of a low carbohydrate diet on performance of pregnant and lactating dogs. J Nutr 111, 678-689

SAS (1985) SAS User's Guide. Statistics. Version 5 Edition SAS Institute Inc, Cary, NC, USA

Schneider PL, Sklan D, Chalupa W, Kronfeld DS (1988) Feeding calcium salts of fatty acids to lactating cows. $\checkmark$ Dairy Sci 71, 2143-2150

Sharma HR, Ingalls JR, McKirdy JA (1978) Replacing barley with protected tallow in ration of lactating $\mathrm{Hol}-$ stein cows. J Dairy Sci 61, 574-583

Sklan D, Bogin E, Avidar Y, Gur-Arie S (1989) Feeding calcium soaps of fatty acids to lactating cows: effect on production, body condition and blood lipids. $J$ Dairy Res 56, 675-681

Smith NE, Dunkley WL, Franke AA (1978) Effects of feeding protected tallow to dairy cows in early lactation. J Dairy Sci 61, 747-756

Sutton JD (1989) Altering milk composition by feeding. $J$ Dairy Sci 72, 2801-2814

Sutton JD, Bines JA, Morant SV, Napper DJ, Givens DI (1987) A comparison of starchy and fibrous concentrates for milk production, energy utilization and hay intake by Friesian cows. J Agric Sci (Camb) 109 , $375-386$ 